\title{
An Empirical Examination of the Compensation-Dividend Relation to Compare Conflict Resolution Strategies at Public versus Private Firms
}

\author{
Amy J. N. Yurko ${ }^{1}$ \\ ${ }^{1}$ Palumbo-Donahue School of Business Duquesne University, Pittsburgh, PA, United States of America \\ Correspondence: Amy J. N. Yurko, Palumbo-Donahue School of Business Duquesne University, Pittsburgh, PA \\ 15282, U.S.A.. \\ Received: February 7, 2018 \\ Accepted: March 2, 2018 \\ Online Published: May 3, 2018 \\ doi:10.5430/afr.v7n2p248 \\ URL: https://doi.org/10.5430/afr.v7n2p248
}

\begin{abstract}
While agency theory predicts that the unification of ownership and control of private family firms reduces agency concerns, some prior studies suggest that the complex family relationships of private, family firms increases agency conflicts. To investigate these conflicting predictions, this study empirically examines with regression analysis how executive total compensation levels relate to dividends at public versus private firms to compare the conflict resolution strategies of public versus private firms. For public firms, this study finds a positive compensation-dividend relation, indicating that public firms increase total compensation levels to reward executives for supporting firms' dividend policies and realign the interests of owners and managers from the conflict created by dividends. Drawing from special access to Forms 1120, this study examines a large sample of privately held U.S. firms. For private firms, this study finds a negative compensation-dividend relation, indicating that private, family firms do not use compensation to realign the interests of owners and managers and overcome the conflict created by dividends. This new evidence suggests that the ownership structure of private, family firms systematically mitigates agency concerns to some degree. On a practical level, this study indicates that firms can provide compensation arrangements that support firms' dividend policies, and that regulatory agencies should continue to focus on public firms where the great dispersion of ownership systematically increases agency concerns.
\end{abstract}

Keywords: executive compensation, dividends, principal agent conflicts, private firms, family firms

JEL Classifications: D21, D22, M12, M52

\section{Introduction}

Researchers have long examined conflict resolution strategies to understand how firms manage agency conflicts (Givoly, Hayn \& Katz, 2010; Jensen \& Meckling, 1976). Agency theory seeks to explain the relation between owners and managers and predicts that agency conflicts increase with the separation of ownership and control (Jensen \& Meckling, 1976). While agency theory developed primarily out of the public firm analysis (Durand \& Vargas, 2003), the prior literature has recognized that private, family firms systematically differ from their public counter parts and that these differences may influence private firm agency conflicts (Lubatkin, Schulze, Ling \& Dino, 2005). Based on the expectation that the unification of ownership and control of private firms generally reduces agency conflicts, regulators have focused on public firms, such that regulations have been a driving force of public firm executive compensation design for the last few decades (Murphy, 2013). However, while there is some evidence that agency concerns are reduced at private firms relative their public counterparts, because of various systematic differences, e.g., enhanced monitoring and altruistic family-firm managers, some prior studies indicate that the unique relationships of family firm members, e.g., destructive nepotism and biased perceptions, may increase agency conflicts (Lubatkin et al., 2005; Miller \& Le Breton-Miller, 2006). To help resolve this conflict, this study extends the prior literature and empirically investigates the relation between two business decisions, executive compensation and dividends, to examine and compare public versus private firm conflict resolution strategies. This study provides new evidence how the agency relations of public firms differ from their private, family controlled counterparts, and evaluates whether family control mitigates agency conflicts to some degree.

To manage agency conflicts, firms should design conflict resolution strategies to realign the interests of owners and managers. Prior literature has identified dividends as a resolution strategy. Because dividends reduce budgetary slack, dividends may help firms manage agency conflicts and improve manager efficiency (Fama \& French, 2002; 
Jiraporn, Kim \& Sang Kim, 2011). However, the reduction in free cash caused by dividends opposes manager preference for greater budgetary slack. Consequently, dividends can be a source of conflict between owners and managers, which firms may overcome by providing compensation arrangements that realign the interests of owners and managers (Fenn \& Liang, 2001; White, 1996). Consistent with this prediction, prior studies have examined public firms and documented that firms can provide executive compensation arrangements that support dividends (White, 1996), or inadvertently suppress dividend payouts (Aboody \& Kasznik, 2008; Fenn \& Liang, 2001; Kahle, 2002). However, few studies have examined how public firms use executive total compensation levels to support firms' dividend policies, providing only mixed, implicit evidence of the total compensation level-dividend relation (Gaver \& Gaver, 1993; Lewellen, Loderer \& Martin, 1987; Smith \& Watts, 1992).

Further, no study to this author's knowledge has examined the executive total compensation-dividend relation of private, family firms. While founding family members may commonly hold equity in public firms, private firms are nearly universally under the control of the founding families (Burkhart, Panunzi \& Shleifer, 2003). The ownership structures of private, family firms may profoundly influence owner-manager conflicts (Schulze, Lubatkin \& Dino, 2003a) and compensation arrangements (Anderson \& Reed, 2003). It has generally been held that unification of ownership and control, inherent to private firms, reduces agency concerns (Jensen \& Meckling, 1976; Miller \& Le Breton-Miller, 2006). Consistent with this proposition, prior studies have documented that ownership concentration increases monitoring, reduces budgetary slack, and minimizes agency costs in general (Ke, Petroni \& Safieddine, 1999; Miller \& Le Breton-Miller, 2006). Firm performance generally benefits from family involvement (Bast, 2010; Lee, 2006; Miller \& Le Breton-Miller, 2006), with longer executive tenure (Schulze et al., 2003a), higher earnings quality (Wang, 2006), and increased loyalty (Lubatkin et al., 2005). Even though private firms are predominantly free from the regulatory constraints of the SEC and the major exchanges, regulars have focused on public firms. For example, perceiving a systematic difference between public and private firms, the U.S. Congress provided Internal Revenue Code Section $162(\mathrm{~m})$ to influence the compensation arrangements of public firm executives (Balsam, 2012; Murphy, 2013), while expressly excluding private firms. (Note 1) However, in contrast to the general perception that the private firm ownership structure systematically reduces agency conflicts, some studies indicate that the complexity of family relationships may create agency problems unique to private firms (Lubatkin et al., 2005). This "dark side" of family firms may increase agency problems, because of improper monitoring, biased perceptions, overt nepotism, and a destructive sense of entitlement associated with founding family members (Lubatkin et al., 2005; Schulze et al., 2003a; Schulze, Lubatkin \& Dino, 2003b).

To examine how the family control of private firms influences agency concerns, this study extends the prior literature and examines the compensation-dividend relation of public and private firms, separately, to compare how public versus private firms use executive total compensation levels to support their dividend policies. To control agency concerns and align the interests of owners and managers, public firms may increase executive compensation levels to motivate the high effort necessary to produce the free cash for dividends. Therefore, I predict that executive total compensation levels and dividends are positively related complements at public firms. If the family firm structure systematically reduces agency conflicts, private firms would have less need to link executive compensation to dividends relative their public counterparts. In other words, if family firm executives are far more concerned with designing compensation arrangements that maximize firm welfare relative to their public firm counterparts, as suggested in prior literature such as Cole and Mehran (2013), firms will have less need to positively link compensation and dividends. Private firms may treat compensation and dividends as reward substitutes, e.g., an increase in compensation levels corresponds with a reduction in dividend payouts. Therefore, I predict that executive total compensation levels are negatively associated with dividends at private firms.

To test these predictions, this study empirically examined the total executive compensation-dividend relation of public and private firms, separately. Confidentiality limits the ability to examine private U.S. firms. To overcome this limitation, this study benefitted from special access to confidential, private firm Forms 1120. (Note 2) This data provides valuable insight into private, family firm behavior that is rarely available to researchers, although limited to the information reported on the Forms 1120. The sample selection and results sections discuss the data and analysis restrictions.

There are both theoretical and practical implications of this study. On a theoretical level, this study provides greater insight into how the agency concerns of private firms compare to public firms. Specifically, do private firms have reduced agency conflicts relative their public counterparts? As a practical matter, these results would indicate that firms can use compensation to realign the interest of owners and managers to support dividend policy, and that regulators should continue to focus on public firms, whose ownership dispersion systematically increases the need for stronger agency controls. 
Section 1.1 presents the background and literature review, and 1.2 presents the hypothesis development. Sections 2 and 3 present the methodology and results, respectively. Section 4 discusses the findings of this study and concludes.

\subsection{Background and Literature Review}

Understanding the motivation of business decisions has long inspired researchers, such as Jensen and Meckling (1976) in their preeminent study. Recognizing that the separation of ownership and control significantly influences decisions, Jensen and Meckling developed an agency theory to examine the relation between owners and managers. Agency theory provides that, because those in control may not make decisions that are in the best interests of the owners, firms should design mechanisms to align the interests of owners and managers, with minimal "agency" costs to maximize shareholder wealth. Prior literature has defined dividends as one of those mechanisms (Jiraporn et al., 2011).

Agency theory predicts that firms pay dividends to reduce budgetary slack, minimize wasteful spending, and compel efficient manager behavior (Fama \& French, 2002). Consistent with this theory, empirical studies have documented a positive relation between a firm's dividend policy and the quality of corporate governance (Jiraporn et al., 2011), higher earnings quality (Skinner \& Soltes, 2011; Tong \& Miao, 2011), higher earnings growth (Arnott \& Asness, 2003) and future earnings (Nissim \& Ziv, 2001). Signaling theory also attempts to explain why firms pay dividends, predicting that firms pay dividends to signal firm value (Allen, Bernardo \& Welch, 2000; Brav, Graham, Harvey, \& Michaely, 2005). Consistent with this theory, dividend announcements and increases are positively related to market value (Docking \& Koch, 2005). To avoid a negative market response, firms generally smooth dividends (Brav et al., 2005) and are slow to reduce an established dividend policy (Arnott \& Asness, 2003).

However, dividends are expensive, reducing free cash. Further, because dividends reduce the free cash for budgetary slack, dividends create a fundamental conflict between owners and managers (White, 1996). Firms can overcome this conflict by providing compensation arrangements to realign the interests of owners and managers (Kahle, 2002; White, 1996). Consistent with this prediction, prior literature has documented that dividend-linked compensation has a positive association with dividends (White 1996). Inadvertently, compensation design can adversely affect dividends. For example, dividend payouts decrease with manager option grants that are not dividend protected (Aboody \& Kasznik, 2008; Fenn \& Liang, 2001; Kahle, 2002). Supporting the proposition that firms can support their dividend policy through increased total compensation levels, the Lewellen et al. (1987) study implicitly found a positive association between dividends and cash compensation levels. However, the Smith and Watts (1992) industry-wide study and the Gaver and Gaver (1993) study implicitly suggested that this positive association may not hold after controlling for the effects of growth opportunities and firm size.

The theories that attempt to explain why public firms pay dividends may not extend to private firms. Agency theory predicts that the unification of ownership and control should reduce agency concerns (Jensen \& Meckling, 1976), and prior studies have documented that ownership concentration increases monitoring, incentivizes managers to manage costs, and minimizes agency costs in general (Ke et al., 1999; Lee, 2006; Miller \& Le Breton-Miller, 2006). Nearly all private firms are under the control of the founding family (Burkhart et al, 2003), with owners commonly serving as managers ( $\mathrm{Gao} \& \mathrm{Li}, 2015$; Lubatkin et al., 2005). Signaling theory predicts that firms pay dividends to signal firm quality to investors, especially to large institutional investors (Allen et al., 2000; Julio \& Ikenberry, 2004). However, private firms may have few or no minority interest shareholders (Michaely \& Roberts, 2012), and shareholders may have no intention to sell their shares (Panunzi, Burkart, \& Shleifer, 2003; Schulze et al., 2003a).

If the family relationships of private firms systematically reduce agency conflicts, then dividends may not create a conflict between owners and managers, which reduces the need to use compensation to realign their interests. Consistent with this proposition, the prior literature has found that the unification of ownership and control has important implications for incentives (Anderson \& Reeb, 2003; Cole \& Mehran, 2013). Firms with greater managerial ownership concentration generally rely less on incentives and provide lower total compensation levels (Cavalluzzo \& Sankaraguruswamy, 2000; Ke et al., 1999), while demonstrating greater performance (Anderson \& Reeb, 2003; Lee, 2006). Family firm compensation arrangements are affected by enhanced monitoring (Lee, 2006), and by the manager serving as a steward of his/her family firm (Miller \& Le Breton-Miller, 2006).

However, some prior literature also indicates that family ownership does not eliminate agency conflicts (Schulze et al., 2003a; Schulze et al., 2003b). Family relationships may lead to unqualified individuals in key management roles (Lubatkin et al., 2005), and improper monitoring of family members (Schulze et al., 2003b). Suggesting that family firms are not immune from agency concerns, private family firms generally incorporate some 
performance-based incentives in executive compensation arrangements, rather than rely solely on low risk salary (Schulze et al., 2003b).

As a practical level, executive compensation practices at public firms dramatically differ from private firms, driven in large part by extensive regulations (Murphy, 2013). The U.S. Securities and Exchange Commission (SEC) has mandated that public firms disclose detailed information on the compensation arrangements of their top executives since 1992, with a dramatic increase in the disclosure requirements in 2006 (Robinson, Xue \& Yu, 2011). Public firms are required to establish independent committees to review compensation practices. (Note 3) To manage the plethora of regulations, public firms commonly rely on professional compensation consulting firms (Murphy, 2013). Public firm executive arrangements are often complex with multiple components having a variety of extended terms, e.g. option awards commonly provide a ten-year exercise period, long-term incentive plans are often based on a three- to five-year rolling-average of cumulative performance (Murphy, 2013), and restricted stock grants typically provide a three- to four-year vesting period (Balsam, 2012).

Because private firms are generally beyond the control of the SEC, private firms are largely unconstrained by the regulations governing public firms. Therefore, compensation may be negotiated behind closed doors with little to no formalized incentive agreements, and renegotiated at will throughout the fiscal year. Consequently, private firm compensation arrangements may differ dramatically from public firms, both procedurally, e.g., easier to modify the arrangements throughout the fiscal year, and substantively, e.g. private firms rely far more heavily on cash incentives than equity awards (Schulze et al., 2003b). Therefore, because of the systematic differences in the agency relations and in the regulatory environment, I expect that private firm compensation arrangements and their relation to dividends systematically differ from their public counterparts.

\subsection{Hypothesis Development}

Public firms have "gone public" to expand their ownership base; separating ownership from control by definition. With less ownership than their private firm counterparts, public firm executives are significantly less concerned with firm welfare (Jensen \& Meckling, 1976), and more inclined to engage in "opportunistic behavior" (Givoly et al., 2010). Therefore, public firms should incorporate mechanisms to resolve these agency conflicts, such as pay dividends that minimize budgetary slack and drive manager efficiency (Jiraporn et al., 2011).

Whereas dividends benefit public firm owners, they reduce the budgetary slack against the preference of executives, who rely primarily on compensation for their reward. Because dividends create a conflict between shareholders and executives, public firms should provide executive compensation arrangements that align the interests of owners and executives to resolve the conflict (White, 1996). In other words, public firms should reward their managers with increased compensation to motivate the effort that produces the free cash for dividends. Therefore, this study predicts that total executive compensation levels and dividends are complements that increase together at public firms, and states the first hypothesis as follows:

Hypothesis I: At public firms, executive total compensation levels are positively related to dividends.

Firms may reward shareholders with dividends and managers with compensation. Since private firm executives generally hold more equity (Goa \& $\mathrm{Li}, 2015)$, i.e. founding family owner-managers $(\mathrm{OM})$, the firm can reward OMs with both compensation and dividends. To minimize taxable income, at the corporate level, firms should prefer rewarding their OMs with compensation. (Note 4) However, at the individual level, OMs would generally prefer dividends. First, since 2003, dividends are subject to a lower individual income tax rate relative compensation. Second, compensation is also subject to payroll taxes, such as Medicare. (Note 5) Lastly, because compensation reduces corporate net income, some incentive plans may be adversely affected by high compensation levels. Therefore, OMs may prefer greater dividend payouts if they are indifferent to firm welfare.

However, a private firm OM may not be indifferent because the value of the family firm is an important component of his/her utility (Schulze et al., 2003b). While the "dark side" of family firms may create some unique agency problems, the "bright side" generally motivates greater long-term firm loyalty in OMs relative to their professional counterparts (Lubatkin et al., 2005). Private firm OMs maintain their ownership longer, perhaps intending to pass it to their heirs (Panunzi et al., 2003; Schulze et al., 2003a). Private firm executives demonstrate significantly longer tenure, and may be far less myopic (Miller \& Le Breton-Miller, 2006; Schulze et al., 2003a), such that OMs' relations with private firms bear little resemblance to that demonstrated by their professional counterparts (Miller \& Le Breton-Miller, 2006). Therefore, dividend and compensation decisions at private firms may be greatly influenced by firm welfare concerns. 
Therefore, while family relations may not eliminate agency conflicts in all circumstances, I expect that the unification of ownership and control of family firms systematically reduces agency concerns. In other words, the benefit from the reduction of agency conflicts, associated with the unification of ownership and control of family firms, may generally exceed any downside from the "dark side" of family relationships. Therefore, rather than using dividends and compensation to realign the interests of owners and managers, I expect that OMs treat compensation and dividends as reward substitutes, and that OMs design a compensation-dividend allocation that satisfies their individual utilities, while influenced by firm welfare considerations. Because I expect that private firms treat compensation and dividends as reward substitutes, i.e., an increase in compensation (dividends) coincides with a reduction in dividends (compensation), this study predicts a negative relation between total executive compensation levels and dividend payouts at private firms, and states the second hypothesis as follows:

Hypothesis II: At private firms, executive total compensation levels are negatively related to dividends.

\section{Methodogy}

\subsection{Research Method}

To test Hypotheses I and II, this study uses a dividend prediction model based on Fama and French's (2002) adaptation of Lintner's (1956) model, Equation (1). Lintner's (1956) model defined a firm's dividend payout, DIV, as a function of its target payout, $T P$, established at the end of the prior year, and the current year's firm performance. Because dividends are paid out of retained earnings, a function of book income, and market returns are not available for the private firm sample, this study measures firm performance with accounting performance, ROA.

$$
D I V_{i, t}=\alpha+T P_{i, t-1} * R O A_{i, t}+\varepsilon
$$

This study follows the Fama and French (2002) models, which defined the dependent variable, DIV, as dividends scaled by total assets, and defined the target payout, $T P$, as a function of various prior year factors that influence dividend payouts, CONTROL VARIABLES, Equation (2).

$$
D_{I V} V_{i, t}=\alpha+\left(\beta_{0}+\sum \beta_{j} \text { CONTROL VARIABLES } S_{i, t-1}\right) * R_{\text {OA }}+\varepsilon
$$

The model includes CONTROL VARIABLES $S_{i, t-I}$ consistent with prior literature (Aboody \& Kasznik, 2008; Fama \& French, 2002; Michaely \& Roberts, 2012), but limited to the data reported by firms on the Forms 1120 . When firm performance produces extra cash, firms can choose to invest in growth opportunities, reduce obligations, or pay dividends. Therefore, dividend payouts are influenced by firm profitability, liquidity, investment opportunities, and leverage (Fama \& French, 2002). Because the selection between dividends and debt affects the firm's interest expense, which is deductible as a tax expense, earnings before interest and taxes, EBIT, measures firm performance. To control for liquidity and cash flow constraint (Aboody \& Kasznik, 2008), the model includes scaled total cash, $C A S H$, and the change in total cash, $\triangle C A S H$, because a firm's cash balance is reported on its annual Form 1120. Growth firms have more investment opportunities. Although market-to-book is commonly included as a proxy for growth opportunities, Forms 1120 do not report market value, preventing the calculation for private firms. To consistently analyze both private and public firms, the model included the firm's scaled change in total assets, $\triangle A S S E T S$, to control for firm growth opportunities (Fama \& French, 2002). The model includes the total book value of property, plant and equipment to control for the assets already in place, PPE (Michaely \& Roberts, 2012), and the change of $P P E$ to control for the growth of noncurrent assets, $\triangle P P E$. $P P E$ and $\triangle P P E$ may also influence dividend payouts because firms with greater tangible assets have a greater debt capacity (Flannery \& Rangan, 2006). Current obligations may have a greater influence on dividend payouts compared to long-term obligations. Therefore, the model includes scaled current liabilities, CURR_LIAB; the change of current liabilities, $\triangle C U R R \_L I A B$; total liabilities, TOTAL_LIAB; and the change of total liabilities, $\triangle T O T A L_{-} L I A B$. Dividend payouts may be affected by firm volatility, proxied by the total book value of assets, ASSETS. Because a firm's interest expense is tax deductible, but dividend payouts are not, the model includes both the firm's annual federal income tax expense, TAX, and interest expense, INTEREST, as controls. Finally, to control for the influence of various omitted variables, and because public firm dividend payouts are sticky (Lintner, 1956), the model includes the scaled, prior year dividend payouts, $D I V_{t-1}$. Year and industry indicators control for year and industry effects.

$$
\begin{aligned}
\text { DIV }_{i, t}=\alpha & +\theta \text { EXEC COMP }_{i, t}+\left(\beta_{0}+\beta_{1} \text { EBIT }_{i, t-1}+\beta_{2} \text { CASH }_{i, t-1}+\beta_{3} \Delta \text { CASH }_{i, t-1}+\beta_{4} \Delta \text { ASSETS }_{i, t-1}\right. \\
& +\beta_{5} \text { PPE }_{i, t-1}+\beta_{6} \Delta P P E_{i, t-1}+\beta_{7} \text { CURR_LIAB }_{i, t-1}+\beta_{8} \Delta \text { CURR_LIAB }_{i, t-1}+\beta_{9} \text { TOTAL_LIAB }_{i, t-1} \\
& \left.+\beta_{10} \Delta T O T A \text { TILLIAB }_{i, t-1}+\beta_{11} \text { ASSETS }_{i, t-1}+\beta_{12} \text { TAX }_{i, t-1}+\beta_{13} \text { INTEREST }_{i, t-1}+\beta_{14} \text { DIV }_{i, t-1}\right) * \text { ROA }_{i, t} \\
& +\sum \text { Year Indicators }+\sum \text { Industry Indicators }+\varepsilon
\end{aligned}
$$


To test Hypothesis I and II, Equation (3) includes the independent variable, EXEC_COMP, defined as the sum total of all reported manager compensation scaled by total book assets. The coefficient of interest, $\theta$ on EXEC_COMP, estimates the relation between total executive compensation levels and dividends, after controlling for the predicted dividend estimated by the Fama and French (2002) model. This method is similar to prior studies that used regression analysis to examine the relation between dividends and compensation (White, 1996), governance (Jiraporn et al., 2011), and stock incentives (Fenn \& Liang, 2001), with independent variables to control for the expected dividend. Subscripts $i$, and $t$ represent firm and year, respectively.

Table 1. Variable Definitions

\begin{tabular}{|c|c|}
\hline Variable & Definition \\
\hline$D I V$ & total dividends, scaled by average total assets \\
\hline EXEC_COMP & $\begin{array}{l}\text { the sum of total manager compensation reported by the firm, scaled by end of year } \\
\text { total assets. For private firms, the total manager compensation is the amount } \\
\text { reported on page } 1 \text {, line } 12 \text { of the firm's Form } 1120 \text {. For public firms, this is the } \\
\text { sum of all executives' total direct compensation reported on ExecuComp. }\end{array}$ \\
\hline EBIT & net income before interest and taxes, scaled by end of year total assets \\
\hline $\mathrm{CASH}$ & cash, scaled by end of year total assets \\
\hline$\triangle C A S H$ & the change of cash from the prior year, scaled by end of year total assets \\
\hline$\triangle A S S E T S$ & the change in total assets, scaled by end of year total assets \\
\hline$P P E$ & gross property, plant and equipment, scaled by end of year total assets \\
\hline$\triangle P P E$ & the change of gross property, plant and equipment, scaled by end of year total assets \\
\hline CURR_LIAB & total current liabilities, scaled by end of year total assets \\
\hline$\triangle C U R R \_L I A B$ & the change of total current liabilities, scaled by end of year total assets \\
\hline TOTAL_LIAB & total liabilities, scaled by end of year total assets \\
\hline$\triangle T O T A L_{-} L I A B$ & the change of total liabilities, scaled by end of year total assets \\
\hline ASSETS & the natural logarithm of end of year total book assets \\
\hline$T A X$ & $\begin{array}{l}\text { federal income tax expense, scaled by net income. For private firms, this is the } \\
\text { firm's total corporate income tax on page } 1 \text {, line } 31 \text {, of the firm's Form } 1120 \text {. }\end{array}$ \\
\hline INTEREST & Interest Expense for the Year \\
\hline$R O A$ & net book income/average total assets \\
\hline
\end{tabular}

Table 1 provides the definition of the Equation (3) variables.

Equation (3) tests the following hypotheses:

$\mathrm{H}_{0}$ : Executive total compensation levels are unrelated to dividends.

$\mathrm{H}_{\mathrm{I}(\mathrm{II})}$ : For public (private) firms, executive total compensation levels are positively (negatively) related to dividends.

Equation (3) examines public and private firms, separately. Using the public (private) firm sample, a statistically significant, $\mathrm{p}<.10$, positive (negative) coefficient on EXEC_COMP provides evidence that firms' total executive compensation levels are positively (negatively) related to dividends, supporting Hypothesis I (II).

\subsection{Sample Selection}

For the publicly traded firms, Compustat North American Fundamentals Annual and Compustat ExecuComp databases supplied the sample data. ExecuComp reports firms on the S\&P 1,500, but includes more than 3,400 firms, since it does not remove firms once included. Because the private firm sample, discussed below, was available for the period 1993 through 2008, this study used this same sample period for the sample of nonfinancial public firms, a total of 32,654 firm-year observations. Excluding firms that did not have executives listed on ExecuComp and observations that lacked the requisite information, a total of 12,443 firm-year observations, the final sample of public firms includes 20,211 firm-year observations, comprised of 2,475 unique firms with a mean (median) of 8 (7) years for each firm. 
For the privately held firms, the Statistics of Income division of the U.S. Internal Revenue Service (IRS) supplied the sample of nonfinancial firm data, using all 1993 through 2008 Forms 1120 filed with the IRS. (Note 6) The following procedures, provided in the next paragraph, define firm admittance into the private firm sample to exclude public firms and "closely-held" small corporations (Note 7), which I define as firms owned by less than five shareholders with less than $\$ 1$ million in assets. Closely-held firms may differ dramatically from firms with multiple shareholders. At a closely-held firm, the shareholder(s) own such a large percentage of the firm, they may see little difference between their personal assets and the firm's. Consequently, courts have long been more likely to pierce the corporate veil of a closely-held firm, and treat the firm as a legal extension of the dominant shareholder (Thompson, 1991). Because these firms' identities may be nearly inseparable from the controlling shareholders, these firms may inject extreme noise into the analysis. In addition, eliminating all firms with less than $\$ 1$ million of total book assets provides a sample of private firms relatively comparable to the public firm sample, but differing primarily in regards to the concentration of firm ownership. (Note 8)

Each Form 1120 is a single, firm-year observation. To eliminate all public firms and closely-held small firms for the reasons described in the preceding development, observations were excluded as follows: First, we excluded all firms that identified themselves as publicly traded on Schedule M-3. The Schedule M-3 is only available post-2003 and required for corporations with more than $\$ 10$ million of total assets. However, corporations with 100 or fewer shareholders are required to report the number of shareholders on Schedule K. Therefore, we next excluded all firms that did not provide this number to exclude public firms, and those with less than five shareholders to exclude the closely-held firms. Third, we excluded all firms with less than $\$ 1$ million total book assets to exclude small, closely-held firms, to identify $1,257,520$ observations that satisfied the sample criteria. Excluding all firms that lacked the Equation (3) information, 677,397 firm-year observations, the final sample of private firms includes 580,123 firm year observations; 140,231 unique firms with a mean of 4.1 years.

Table 2: Descriptive Statistics of Public Firms

\begin{tabular}{|c|c|c|c|c|c|}
\hline \multirow[b]{2}{*}{ PANEL A: } & \multirow[b]{2}{*}{$\mathrm{n}$} & \multirow[b]{2}{*}{ Mean } & \multicolumn{2}{|l|}{ Lower } & \multirow{2}{*}{$\begin{array}{l}\text { Upper } \\
\text { Quartile }\end{array}$} \\
\hline & & & Quartile & Median & \\
\hline Total Assets (in millions) & 20211 & 4588 & 378 & 1030 & 3291 \\
\hline \multicolumn{6}{|l|}{ NET INCOME (in millions): } \\
\hline Book Income & 20211 & 202 & 8 & 41 & 150 \\
\hline before interest and taxes & 20211 & 412 & 25 & 84 & 286 \\
\hline Total Dividends (in millions) & 20211 & 88 & 0 & 2 & 31 \\
\hline Total Compensation (in thousands) & 20211 & 10547 & 3170 & 5865 & 11812 \\
\hline \multicolumn{6}{|c|}{ EQUATION (3) INDEPENDENT VARIABLES: } \\
\hline$R O A$ & 20211 & 0.036 & 0.016 & 0.051 & 0.093 \\
\hline EBIT & 20211 & 0.083 & 0.055 & 0.094 & 0.143 \\
\hline $\mathrm{CASH}$ & 20211 & 0.092 & 0.015 & 0.048 & 0.126 \\
\hline$\triangle C A S H$ & 20211 & 0.010 & -0.010 & 0.002 & 0.027 \\
\hline$\triangle A S S E T S$ & 20211 & 0.089 & 0.001 & 0.077 & 0.183 \\
\hline$P P E$ & 20211 & 0.575 & 0.274 & 0.499 & 0.817 \\
\hline$\triangle P P E$ & 20211 & 0.044 & 0.011 & 0.037 & 0.076 \\
\hline CURR_LIAB & 20211 & 0.242 & 0.146 & 0.213 & 0.300 \\
\hline$\triangle C U R R \_L I A B$ & 20211 & 0.020 & -0.008 & 0.018 & 0.052 \\
\hline$T O T A L \_L I A B$ & 20211 & 0.534 & 0.368 & 0.533 & 0.663 \\
\hline$\triangle T O T A L \_L I A B$ & 20211 & 0.043 & -0.016 & 0.030 & 0.094 \\
\hline ASSETS & 20211 & 6.961 & 5.806 & 6.843 & 8.007 \\
\hline$T A X$ & 20211 & 0.285 & 0.026 & 0.292 & 0.486 \\
\hline INTEREST & 20211 & 0.199 & 0.003 & 0.130 & 0.437 \\
\hline
\end{tabular}


PANEL B: Public firm sample by industry

\begin{tabular}{lc}
\hline Fama/French 12-Industry Classification & Observations \\
\hline Consumer Non-Durables & 1557 \\
Consumer Durables & 711 \\
Manufacturing & 3004 \\
Energy & 875 \\
Chemicals \& Allied Products & 772 \\
Business Equipment & 3998 \\
Telephone \&Television & 616 \\
Utilities & 1264 \\
Shops & 2965 \\
Health & 1969 \\
Other & 2480 \\
\hline TOTAL & 20211 \\
\hline
\end{tabular}

Table 2 Panel A shows the descriptive statistics of the U.S. publicly traded firm data, including the Equation (3) independent variables. See Table 1 for variable definitions. Mean (median) total book assets equal $\$ 4.5(\$ 1.0)$ billion. The mean (median) natural log of total assets, ASSETS, is 6.961 (6.843), which is comparable to the dividend paying firms in the Tong and Miao (2011) study with 6.275 (6.244). Mean (median) ROA is 0.036 (0.051), slightly lower than the Tong and Miao (2011) sample, 0.064 (0.062), but comparable to the Aboody and Kasznik (2008) study sample of firms with $0.04(0.04)$. The public firm sample paid mean (median) dividends of $\$ 88$ (\$2) million and reported a sum total annual manager compensation of $\$ 10.5$ (\$5.9) million. Table 2 Panel B presents the public firm sample breakdown by industry. (Note 9) The Pearson correlation matrix of the CONTROL VARIABLES indicates that firm net income before interest and taxes is positively associated with the increase in cash, growth opportunities, and increases in fixed assets. (Note 10)

Because of data access restrictions imposed at the conclusion of the analysis, intended to protect taxpayer confidentiality and minimize the risk of a security breach, this study's access to all Forms 1120 filed with the IRS was affected, which severely limited the ability to provide the private firm sample descriptive statistics. The criteria for admittance into the private firm sample, defined above, was carefully followed to protect the integrity of the analysis. The private firms must have had a minimum of five shareholders, $\$ 1$ million in total book assets, and had reported all of the variables required for the analysis. Within these restrictions, this study examines a large segment of the U.S. economy that is generally beyond the reach of researchers: all U.S. privately held corporations, and not an isolated subsample. Treasury Department data is now tightly guarded, with researchers commonly limited to subsamples of firms, generally large public firms, to minimize security risks. While recognizing the data limitations, this study's examination of all U.S. privately held corporations provides valuable insight into private firm business decisions that outweighs those limitations.

\section{Results}

Table 3 presents the results, which support both hypotheses. Because the results are contrasting, a positive public firm relation versus a private firm relation, the results provide a robust distinction between public versus private firms.

Column one of Table 3 presents the public firm results. The coefficient on EXEC_COMP is positive and statistically significant $(0.00003, \mathrm{p}=0.002)$. These results support Hypothesis I, indicating that dividends increase with executive total compensation levels at public firms. This finding suggests that firms increase executive compensation levels to reward executives for producing the free cash flow for dividends, consistent with White's (2006) proposition that firms use compensation to realign the interests of owners and managers, resolving the conflict created by dividends.

Of particular note, the executive total compensation level-dividend positive relation holds even after controlling for firm growth opportunities. The negative coefficient on GROWTH $(-0.0266, \mathrm{p}<0.001)$ is consistent with prior literature, which documented that growth firms pay lower dividends (Fama \& French, 2001). (Note 11)

Column two of Table 3 presents the private firm results. The coefficient on EXEC_COMP is negative and statistically significant, $(-0.0017, \mathrm{p}=0.044)$, providing evidence of a negative relation between dividends and 
executive total compensation levels. This finding suggests that private firm owner-managers treat dividends and compensation as reward substitutes. In other words, OMs do not reward themselves with greater compensation levels for producing dividends as seen in public firms, but trade-off receiving their reward in the form of compensation or dividends. These results suggest that private firms do not use compensation to support a firm's dividend policy in a manner comparable to that seen at public firms, and that agency relations at private firms differ significantly from public firms, consistent with prior literature (Anderson \& Reeb, 2003; Cole \& Mehran, 2013).

Table 3: Equation (3) Results: Examination of the relation of total executive compensation levels and dividends

\begin{tabular}{|c|c|c|c|c|c|}
\hline \multirow{2}{*}{$\begin{array}{l}\text { Variable } \\
\text { Intercept }\end{array}$} & \multirow[t]{2}{*}{ prediction } & \multicolumn{2}{|c|}{ PUBLIC FIRMS } & \multicolumn{2}{|c|}{ PRIVATE FIRMS } \\
\hline & & 0.0100 & $* * *$ & 0.0140 & $* * *$ \\
\hline & & $(<.001)$ & & $(<.001)$ & \\
\hline \multirow[t]{2}{*}{ EXEC_COMP } & H1: public firms $(+)$ & 0.00003 & $* * *$ & -0.0017 & $* *$ \\
\hline & $\mathrm{H} 2$ : private firms (-) & $(0.002)$ & & $(0.044)$ & \\
\hline \multirow[t]{2}{*}{$R O A$} & & -0.1292 & $* * *$ & 0.0484 & $* * *$ \\
\hline & & $(<.001)$ & & $(<.001)$ & \\
\hline \multirow[t]{2}{*}{ EBIT } & & 0.0150 & $* * *$ & 0.0000 & $* * *$ \\
\hline & & $(<.001)$ & & $(<.001)$ & \\
\hline \multirow[t]{2}{*}{$\mathrm{CASH}$} & & 0.1122 & $* * *$ & -0.0066 & $* * *$ \\
\hline & & $(<.001)$ & & $(<.001)$ & \\
\hline \multirow[t]{2}{*}{$\triangle C A S H$} & & -0.0219 & $* * *$ & 0.0001 & $* * *$ \\
\hline & & $(<.001)$ & & $(<.001)$ & \\
\hline \multirow[t]{2}{*}{$\triangle A S S E T S$} & & -0.0266 & $* * *$ & -0.00002 & $* *$ \\
\hline & & $(<.001)$ & & $(0.029)$ & \\
\hline \multirow[t]{2}{*}{$P P E$} & & 0.0056 & $*$ & -0.0020 & $* * *$ \\
\hline & & $(0.056)$ & & $(<.001)$ & \\
\hline \multirow[t]{2}{*}{$\triangle P P E$} & & 0.0129 & $* * *$ & 0.00002 & $* * *$ \\
\hline & & $(<.001)$ & & $(0.006)$ & \\
\hline \multirow[t]{2}{*}{ CURR_LIAB } & & -0.0116 & $* * *$ & -0.0001 & $* * *$ \\
\hline & & $(<.001)$ & & $(<.001)$ & \\
\hline \multirow[t]{2}{*}{$\triangle C U R R \_L I A B$} & & -0.0050 & & 0.00003 & $* * *$ \\
\hline & & $(0.261)$ & & $(<.001)$ & \\
\hline \multirow[t]{2}{*}{$T O T A L \_L I A B$} & & 0.0088 & $* * *$ & 0.0000 & \\
\hline & & $(<.001)$ & & $(0.474)$ & \\
\hline \multirow[t]{2}{*}{$\triangle T O T A L \_L I A B$} & & -0.0117 & $* *$ & 0.00001 & $* * *$ \\
\hline & & $(0.013)$ & & $(<.001)$ & \\
\hline \multirow[t]{2}{*}{ ASSETS } & & 0.0204 & $* * *$ & -0.0021 & $* * *$ \\
\hline & & $(<.001)$ & & $(<.001)$ & \\
\hline \multirow[t]{2}{*}{$T A X$} & & 0.0043 & $* * *$ & 0.0001 & $* * *$ \\
\hline & & $(<.001)$ & & $(0.005)$ & \\
\hline \multirow[t]{2}{*}{ INTEREST } & & -0.0007 & & 0.0004 & $* * *$ \\
\hline & & $(0.269)$ & & $(0.001)$ & \\
\hline \multirow[t]{2}{*}{$D I V_{t-1}$} & & 0.1503 & $* * *$ & 0.0002 & $* * *$ \\
\hline & & $(<.001)$ & & $(<.001)$ & \\
\hline R-square & & 0.1076 & & 0.0272 & \\
\hline F Value & & 59.33 & & 524.08 & \\
\hline $\mathrm{n}$ & & 20,211 & & 580,123 & \\
\hline
\end{tabular}


Table 3 presents the results of OLS regressions with year and industry fixed effects, coefficients not presented for brevity, with $\mathrm{p}$ values presented in parenthesis. $* * *, * *$, and * indicate that statistical significance is demonstrated at the $.01, .05$, and .10 levels, respectively. Table 1 presents the variable definitions.

Collinearity tests indicate that the Condition Index is less than 10 and the VIF is less than 15 for the public firm sample.

Endogeniety is a concern for panel estimations. However, there are multiple methods to minimize estimation biases (Reeb, Sakakibara \& Manmood, 2012). This paper attempts to control for endogeneity in two ways. First, the model includes the lag of the dependent variable, which helps to make the model a dynamic random effects regression controlling for unobserved factors (Cassiman \& Golovko, 2011). Second, comparison studies of two groups provide some degree of control for endogeneity (Cassiman \& Golovko, 2011; Reeb et al., 2012). This study compares public to private firms. Unobserved characteristics common to both types of firms should have a similar effect on both estimations. Those unobserved characteristics that are systematically linked to public or private firms are, by definition, inherently linked to each type of firm. In other words, these latter unobserved characteristics are what distinguished public from private firms and likely contribute to the contrasting results. Because the results provide a clear contrast, a positive dividend-compensation relation of public firms compared to a negative relation of private firms, the empirical results are strong evidence of a systematic difference between the two groups.

This study's method of analysis developed from prior literature, but was limited to the information reported on tax returns and by the private firm sample restrictions imposed because of confidentiality and security concerns. Even though these restrictions limit the study's ability to provide additional descriptive and analyses, the value of the information provided by this study, specific rare insight into private firm business decisions using a large sample of U.S. private, family firms, outweighs the restrictions.

\section{Discussion and Conclusion}

Because this study identifies a statistically significant positive relation between compensation and dividends at public firms and a negative relation of private firms, the contrast provides robust evidence that public firm resolution strategies differ and, therefore, agency relations differ from their private counterparts. While public firms incentivize executives with greater total compensation levels to support their dividend policy, private firms do not positively link compensation to dividends. This contrast presents new evidence that the inherent characteristics of private, family firms systematically reduces agency conflicts at private firms relative public firms.

First, the evidence supports the agency theory prediction that compensation can be used to realign the interests of owners and managers to manage the conflict created by dividends, consistent with White (1996). To control agency conflicts and on a practical level, these results suggest that public firms should treat compensation and dividends as reward complements to motivate the executive effort necessary to support firms' dividend policies.

Second, because private firms do not positively link compensation to dividends, the evidence indicates that private firms do not use compensation to overcome the conflict created by dividends. Therefore, for private firms, this evidence supports the agency theory prediction that the unification of ownership and control seen at private, family firms reduces agency conflicts. While family relationships may have a "dark side" that creates some agency concerns in some situations, this study provides new evidence that the "bright side" of family relationships systematically mitigates agency conflicts to some degree. These findings suggest that private firms treat dividends and compensation as reward substitutes, in which owner-managers effectively trade-off rewarding themselves with compensation or dividends. On a practical level, our results suggest that regulators should continue to focus on public firms, whose ownership dispersion systematically increases the need for stronger agency controls.

In summary, to examine how the family control of private firms influences agency concerns, this study examines the compensation-dividend relation of public and private firms, separately, to compare how public versus private firms use executive total compensation levels to support their dividend policies. Prior literature has not provided this comparison, likely because of data limitations. To extend the prior literature and provide this comparison, this study benefitted from special access to all Forms 1120 filed by all U.S. private firms, producing evidence of a negative compensation-dividend relation of private firms, opposite the positive relation of public firms.

This study sets the stage for future research. First, the empirical analysis was designed to specifically fit the data available from the Forms 1120. With a different source of private firm information, a future study could estimate Equation (3) using alternative control variables to confirm these results. Second, this study provides evidence that agency conflicts weaken at private firms relative their public counterparts. These findings may be explained by the unification of ownership and control of private firms, or also by the increased monitoring associated with private 
firms. Forms 1120 do not provide ownership information. This study's natural extension could be to examine whether the negative compensation-dividend relation of private firms strengthens as manager ownership increases, to evaluate whether managerial ownership or monitoring explains this study's findings. Lastly, this study sets the stage for researchers to compare the compensation practices of other nations to examine how culture and economic environments influence public and private agency relations.

\section{Acknowledgments}

This author appreciates the comments of J. Harry Evans and Mei Feng of the University of Pittsburgh, Steven Balsam of Temple University, and Ronald J. Yurko, Jr. of Carnegie Mellon University. I also appreciate the valuable research assistance of Gerald Gersky of the Statistics of Income division of the Internal Revenue Service.

\section{References}

Aboody, D., \& Kasznik, R. (2008). Executive stock-based compensation and firms' cash payout: the role of shareholders' tax-related payout preferences, Review of Accounting Studies, 13, 216-251. https://doi.org/10.1007/s11142-008-9068-1

Allen, F., Bernardo, A., \& Welch, I. (2000). A theory of dividends based on tax clienteles, The Journal of Finance, 55(6): 2499-2536. https://doi.org/10.1111/0022-1082.00298

Anderson, R., \& Reeb, D. (2003). Founding-family ownership and firm performance: evidence from the S\&P 500, The Journal of Finance, 58(3), 1301-1328. https://doi.org/10.1111/1540-6261.00567

Arnott, R., \& Asness, C. (2003). Surprise! higher dividends = higher earnings growth, Financial Analysts Journal, 59(1), 70-87. https://doi.org/10.2469/faj.v59.n1.2504

Balsam, S. (2012). Taxes and Executive Compensation, EPI Briefing Paper \#344, as of March 30, 2017, Retrieved from http://www.epi.org/publication/taxes-executive-compensation/

Bast, A. (2010, December 29). In Hard Times, Family Firms Do Better, Newsweek, Retrieved from http://www.newsweek.com/family-owned-businesses-get-through-hard-times-69069

Brav, A., Graham, J.R., Harvey, C.R., \& Michaely, R. (2005). Payout policy in the $21^{\text {st }}$ century, Journal of Financial Economics, 77, 483-527. https://doi.org/10.1016/j.jfineco.2004.07.004

Burkart, M., Panunzi, F., \& Shleifer, A. (2003). Family Firms, The Journal of Finance, 58(5), 2167-2201. https://doi.org/10.1111/1540-6261.00601

Cassiman, B., \& Golovko, E. (2011). Innovation and internationalization through exports, Journal of International Business Studies, 42(1), 56-75. https://doi.org/10.1057/jibs.2010.36

Cavalluzzo, K., \& Sankaraguruswamy, S. (2000). Pay-to-Accounting Performance and Ownership Structure in Privately-Held Small Corporations, Working Paper, Georgetown University. Retrieved from https://papers.ssrn.com/sol3/papers.cfm?abstract_id=241154

Cole, R., \& Mehran, H. (2013). What do we know about executive compensation at privately held firms? FRB of New York Staff Report No. 314.

Docking, D.S., \& Koch, P.D. (2005). Sensitivity of investor reaction to market direction and volatility: Dividend change announcements, The Journal of Financial Research, 28(1), 21-40. https://doi.org/10.1111/j.1475-6803.2005.00112.x

Durand, R., \& Vargas, V. (2003). Ownership, organization, and private firms' efficient use of resources, Strategic Management Journal, 24, 667-675. https://doi.org/10.1002/smj.321

Fama, E., \& French, K. (2002). Testing trade-Off and pecking order predictions about dividends and debt, The Review of Financial Studies, 15(1), 1-33. https://doi.org/10.1093/rfs/15.1.1

Fama, E., \& French, K. (2001) 'Disappearing dividend: changing firm characteristics or lower propensity to pay?' Journal of Financial Economic 60, 3-43. https://doi.org/10.1016/S0304-405X(01)00038-1

Fenn, G.W., \& Liang, N. (2001). Corporate payout policy and managerial stock incentives, Journal of Financial Economics, 60, 45-72. https://doi.org/10.1016/S0304-405X(01)00039-3

Flannery, M., \& Rangan, K. (2006). Partial adjustment toward target capital structures, Journal of Financial Economics, 79(3), 469-506. https://doi.org/10.1016/j.jfineco.2005.03.004 
Gao, H., \& Li, K. (2015). A comparison of CEO pay-performance sensitivity in privately-held and public firms, Journal of Corporate Finance, 35, 370-388. https://doi.org/10.1016/j.jcorpfin.2015.10.005

Gaver, J., \& Gaver, K. (1993). Additional evidence on the association between the investment opportunity set and corporate financing, dividend, and compensation policies, Journal of Accounting and Economics, 16(1-3), 125-160. https://doi.org/10.1016/0165-4101(93)90007-3

Givoly, D., Hayn, C.K., \& Katz, S.P. (2010). Does public ownership of equity improve earnings quality? The Accounting Review, 85(1), 195-225. https://doi.org/10.2308/accr.2010.85.1.195

Jensen, M.C., \& Meckling, W.H. (1976). Theory of the firm: managerial behavior, agency costs and ownership structure, Journal of Financial Economics, 3, 305-360. https://doi.org/10.1016/0304-405X(76)90026-X

Jiraporn, P., Kim, J., \& Sang Kim, Y. (2011). Dividend payouts and corporate governance quality: An empirical investigation, The Financial Review, 46, 251-279. https://doi.org/10.1111/j.1540-6288.2011.00299.x

Julio, B., \& Ikenberry, D. (2004). Reappearing dividends, Journal of Applied Corporate Finance, 16(4), 89-100. https://doi.org/10.1111/j.1745-6622.2004.tb00676.x

Kahle, K.M. (2002). When a buyback isn't a buyback: open market repurchases and employee options, Journal of Financial Economics, 63, 235-261. https://doi.org/10.1016/S0304-405X(01)00095-2

Ke, B., Petroni, K., \& Safieddine, A. (1999). Ownership concentration and sensitivity of executive pay to accounting performance measures: Evidence from publicly and privately-held insurance companies, Journal of Accounting and Economics, 28, 185-209. https://doi.org/10.1016/S0165-4101(99)00021-X

Lee, J. (2006). Family firm performance: further evidence, Family Business Review, 19(2), 103-114. https://doi.org/10.1111/j.1741-6248.2006.00060.x

Lewellen, W., Loderer, C., \& Martin, K. (1987). Executive compensation and executive incentive problems: an empirical analysis, Journal of Accounting and Economics, 9(3), 287-310. https://doi.org/10.1016/0165-4101(87)90009-7

Lintner, J. (1956). The distribution of incomes of corporations among dividends, retained earnings, and taxes, American Economic Review, 46(2), 97-113.

Lubatkin, M.H., Schulze, W.S., Ling, Y., \& Dino, R.N. (2005). The effects of parental altruism on the governance of family-managed firms, Journal of Organizational Behavior, 26, 313-330. https://doi.org/10.1002/job.307

Michaely, R., \& Roberts, M. (2012). Corporate dividend policies: lessons from private firms, The Review of Financial Studies, 25(3), 711-746. https://doi.org/10.1093/rfs/hhr108

Miller, D., \& Le Breton-Miller, I. (2006). Family governance and firm performance: agency, stewardship, and capabilities, Family Business Review, 19(1), 73-87. https://doi.org/10.1111/j.1741-6248.2006.00063.x

Murphy, K. J. (2013). Executive compensation: Where we are, and how we got there, Handbook of the Economics of Finance, North Holland, Constantinides, Harris and Stulz (eds.) 211-356.

Nissim, D. \& Ziv, A. (2001). Dividend changes and future profitability, The Journal of Finance, 61(6), 2111-2133. https://doi.org/10.1111/0022-1082.00400

Panunzi, F., Burkart, M., \& Shleifer, A. (2003). Family firms, Journal of Finance, 58(5), $2167-2202$. https://doi.org/10.1111/1540-6261.00601

Reeb, D., Sakakibara, M., \& Mahmood, I.P. (2012). From the Editors: Endogeneity in international business research, Journal of International Business Studies, 43(3), 211-218.

Robinson, J.R., Xue, Y., \& Yu, Y. (2011). Determinants of Disclosure Noncompliance and the Effect of the SEC Review: Evidence from the 2006 Mandated Compensation Disclosure Regulations, The Accounting Review, 86(4), 1415-1444. https://doi.org/10.2308/accr-10033

Schulze, W., Lubatkin, M., \& Dino, R. (2003a). Exploring the agency consequences of ownership dispersion among the directors of private family firms, The Academy of Management Journal, 46(2), 179-194. https://doi.org/10.2307/30040613

Schulze, W., Lubatkin, M., \& Dino, R. (2003b). Toward a theory of agency and altruism in family firms, Journal of Business Venturing, 18, 473-490. https://doi.org/10.1016/S0883-9026(03)00054-5 
Skinner, D., \& Soltes, E. (2011). What do dividends tell us about earnings quality? Review of Accounting Studies, 16, 1-28. https://doi.org/10.1007/s11142-009-9113-8

Smith, C. Jr., \& Watts, R. (1992). The investment opportunity set and corporate financing, dividend, and compensation policies, Journal of Financial Economics, 32(3), 263-292. https://doi.org/10.1016/0304-405X(92)90029-W

Thompson, R.B. (1991). Piercing the Corporate Veil: An Empirical Study, Cornell Law Review, 76(5), 1035-1074.

Tong, Y., \& Miao, B. (2011). Are dividends associated with the quality of earnings? Accounting Horizons, 25(1), 183-205. https://doi.org/10.2308/acch.2011.25.1.183

Want, D. (2006) Founding Family Ownership and Earnings Quality, Journal of Accounting Research, 44(3), 619-656. https://doi.org/10.1111/j.1475-679X.2006.00213.x

White, L. F. (1996). Executive compensation and dividend policy, Journal of Corporate Finance, 2, 335-358. https://doi.org/10.1016/0929-1199(96)00003-X

\section{Notes}

Note 1. I.R.C. $\$ 162(\mathrm{~m})$ defines the federal corporate income tax deduction for public firm executives, limiting the tax deduction of compensation in excess of in excess of $\$ 1$ million.

Note 2. The private firm analysis was performed at the Statistics of Income division of the U.S. Internal Revenue Service. This study benefitted from access to all Forms 1120 filed with the IRS, and not a subdivision as is the general, current practice. Confidential information serves as the basis for the private firm analysis, but no confidential information is disclosed in this paper. This author thanks the division for its valuable assistance.

Note 3. Since 1994, Section 162(m) required to preserve the compensation federal income tax deduction. Since 2003, the SEC required for all public firms.

Note 4. Private firms are exempt from $\S 162(\mathrm{~m})$, but still subject to $\S 162(\mathrm{a})$ 's general requirement that expenses must be "ordinary" and "necessary" to be tax deductible

Note 5. This includes both the Social Security and Medicare portion of the FICA taxes, and the Medicare penalty for higher income taxpayers.

Note 6. Because of data restrictions imposed at the conclusion of the analysis, this study is unable to provide the number of firms initially included and excluded in each step of the sample selection process. However, the Sample Selection Section offers the specific selection criteria used to exclude firms from the sample.

Note 7. The exclusion of closely-held firms serves to bias this study against finding results that support Hypothesis II. There is little reason for closely-held corporations to not increase bonuses to minimize accumulated earnings and profits and avoid the double-tax associated with dividends (Cole \& Mehran, 2013).

Note 8. Manager equity is unavailable for the private firm sample. However, the prior literature has consistently documented that private firms are nearly universally family controlled firms, owned and managed, and that private firm managers commonly own significant interests in their firms, which greatly exceed that held by public firm executives (Burkhart et al., 2003; Gao \& Li, 2015).

Note 9. Financial institutions excluded. Information regarding the Fama French 12-Industry Classification is available at http://mba.tuck.dartmouth.edu/pages/faculty/ken.french/Data_Library/det_12_ind_port.html

Note 10. The correlation matrix is not presented for brevity, but is available upon request.

Note 11. In untabulated results, the public firm results still hold if "market-to-book" serves as the proxy for firm growth opportunities 